\title{
Rosmanol induces breast cancer cells apoptosis by regulating PI3K/AKT and STAT3/JAK2 signaling pathways
}

\author{
DONGJUN JIANG $^{1 *}$, JIAQI XU ${ }^{1}$, SITONG LIU ${ }^{1}$, MOUSSA IDE NASSER $^{1}$, WEI WEI ${ }^{1}$, \\ TIANJIAO MAO ${ }^{2}$, XINTONG LIU ${ }^{3}$, XIAOPAN ZOU ${ }^{1}$, JIANG LI $^{2 *}$ and XIAOMENG LI ${ }^{1 *}$ \\ ${ }^{1}$ The Key Laboratory of Molecular Epigenetics of Ministry of Education (MOE), School of Life Sciences, Northeast \\ Normal University, Changchun, Jilin 130024; ${ }^{2}$ Department of Stomatogy, Affiliated Stomatological Hospital of Guangzhou \\ Medical University, Guangzhou, Guangdong 510180, P.R. China; ${ }^{3}$ Bioprobe Application Research Unit, Chemical \\ Biology Department, RIKEN-Max Planck Joint Research Division, RIkagaku KENkyusho/Institute of Physical and \\ Chemical Research (RIKEN) Center for Sustainable Resource Science, Wako, Saitama 351-0198, Japan
}

Received August 14, 2020; Accepted June 7, 2021

DOI: $10.3892 / \mathrm{ol} .2021 .12892$

\begin{abstract}
Breast cancer is one of the most frequently diagnosed cancers amongst women; however, there is currently no effective treatment. Natural compounds are considered to contribute to cancer prevention and have a pivotal role in modulating apoptosis. Rosmanol is a phenolic diterpene compound with antioxidant and anti-inflammatory properties. In the present study, the effects of Rosmanol on breast cancer cell proliferation/apoptosis were investigated, and it was demonstrated that it inhibited the proliferation of MCF-7 and MDA-MB 231 cells but did not have a significant effect on normal human breast MCF-10A cells. In addition, the apoptotic process was accelerated by Rosmanol, through mitochondrial pathways and reactive oxygen species (ROS) production caused by DNA damage, which function further demonstrated by the attenuation and addition of the ROS inhibitor, $\mathrm{N}$-acetyl-cysteine. It was also demonstrated that Rosmanol accelerated cell apoptosis, and arrested breast cancer cells in the S phase. Moreover, Rosmanol inhibited proliferation and promoted apoptosis of cancer cells via the inhibition of ERK and STAT3 signals, attributable to the increase in p-p38, the overexpression of protein inhibitor of activated STAT3, and the decrease in PI3K/AKT, ERK and JAK2/STAT3.
\end{abstract}

Correspondence to: Professor Xiaomeng Li, The Key Laboratory of Molecular Epigenetics of Ministry of Education (MOE), School of Life Sciences, Northeast Normal University, 5268 People's Street, Changchun, Jilin 130024, P.R. China

E-mail: lixm441@nenu.edu.cn

Professor Jiang Li, Department of Stomatogy, Affiliated Stomatological Hospital of Guangzhou Medical University, 195 Dongfengxi Road, Guangzhou, Guangdong 510180, P.R. China E-mail: 1jiang@gzhmu.edu.cn

*Contributed equally

Key words: apoptosis, Rosmanol, STAT3, JAK2

\section{Introduction}

Breast cancer is undoubtedly one of the most severe heterogeneous diseases affecting women worldwide, resulting in $>500,000$ deaths every year (1). Various efforts are being devoted to overcoming this critical issue, culminating in prevention, diagnosis, and treatment. More specifically, breast cancer can bes treated by surgical, chemotherapeutic or radiotherapeutic methods that differ in their actions $(2,3)$. Nevertheless, these approaches are effective only at the earlier stages, and because of their disadvantages, including high toxicity, side effects and inefficiencies for long-term use, they have failed to realize the cancer therapy (4).

Meanwhile, natural drugs have emerged as alternative methods to treat breast cancer because of their low side effects, high selectivity, safety and effectiveness. Some of the most promising natural anticancer drugs are phenolic compounds (5). The antitumor efficiency of natural phenolics has been associated with their strong anti-inflammatory and antioxidant activities and their ability to moderate molecular targets as well as signaling pathways, which are associated with cell differentiation (6). Rosmanol is a phenolic diterpene obtained from various plants, including Salvia officinalis, Hyptisincana and Rosmarinus. They have been used as potent antioxidants and anti-inflammatories due to their superoxide anion production inhibition capabilities as well as lipid peroxidation and free radical scavenging activities (7). Moreover, Rosmanol inhibited iNOS and COX-2 gene and protein expression as well as their downstream products, NO and PGE2, respectively (8), which causes decreased translocation of nuclear factor- $\kappa \mathrm{B}$ (NF- $\mathrm{B}$ ) subunits (9). As previously reported, Rosmanol also inhibits the proliferation of human colon and neuroblastoma cancer (10).

In total, $\sim 80 \%$ of breast cancers express the estrogen receptor $\alpha(\mathrm{ER} \alpha)$ and the progesterone receptor (PR). ER is a steroid hormone receptor, comprised of $\mathrm{ER} \alpha$ and $\mathrm{ER} \beta$, in which the ER $\alpha$ content in cells is higher than that in normal breast tissue in estrogen-dependent breast cancers (11). Overexpression of ER $\beta$ and inhibition of $\operatorname{ER} \alpha$ have been 
shown to have anti-tumor effects against breast cancer in cells (12).

Moreover, the PI3K/AKT pathway serves an important role in breast cancer development (13). Estrogen receptor $\alpha$-positive breast cancers adapt to hormone deprivation and acquire resistance to antiestrogen therapies. NF- $\kappa \mathrm{B}$ is a downstream component of the PI3K/Akt pathway and is activated via phosphorylation of IкB kinase (IKK) (14).

Certain researchers have attempted to assess the function of JAK2 knockout in the acceleration of cell apoptosis, autophagy and inhibition of proliferation, and this is an important research direction for cancer therapy in the future (15-17). Notably, cytokines and growth factors unanimously use Janus kinase (JAK) as the signal transducer and further activate the [JAK/signal transducer and activator of transcription (STAT3)] pathway transcription (18). Additionally, STAT3 serves a key role in activating cell proliferation and growth in cancer cells, such as breast cancer cells (19). In addition to regulating STAT3, JAK2 signaling also regulates p38 and ERK signaling (20). The above are some important proliferation signals for breast cancer, which promote cell proliferation and inhibit cell apoptosis.

Despite its intense biological response, to the best of our knowledge the effects of Rosmanol on breast cancer have not been previously investigated. Accordingly, the present research aimed to investigate the effects of Rosmanol on proliferation and apoptosis in breast cancer, and to further reveal the associated mechanism by detecting the effects of Rosmanol on the p38, PI3K/Akt/ERK, and STAT3/JAK2 pathways.

\section{Materials and methods}

Cell culture. MCF-10A, MCF-7 and MDA-MB 231 cells were purchased from the American Type Culture Collection. Normal human breast MCF-10A cells were cultured in DMEM/F12 (1:1) media supplemented with 5\% horse serum (Gibco; Thermo Fisher Scientific, Inc.), $1.2 \mathrm{mg} / \mathrm{ml} \mathrm{NaHCO}$ (Sigma-Aldrich; Merck KGaA) 500 ng/ml hydrocortisone (Sangon Biotech Co., Ltd.), $10 \mu \mathrm{g} / \mathrm{ml}$ human insulin (Gibco; Thermo Fisher Scientific, Inc.), $10 \mathrm{ng} / \mathrm{ml}$ hunan recombinant epidermal growth factor (Sigma-Aldrich; Merck KGaA) and $100 \mathrm{ng} / \mathrm{ml}$ cholera toxin (Sigma-Aldrich; Merck KGaA). The two human breast cancer cell lines, MCF-7 and MDA-MB 231, were cultured and maintained in DMEM containing $10 \%$ fetal bovine serum (FBS; Gibco, Thermo Fisher Scientific, Inc). The cells were cultured at $37^{\circ} \mathrm{C}$ in a humidified atmosphere of $5 \% \mathrm{CO}_{2}$ and allowed to grow to a confluence of $70-80 \%$.

Cell proliferation assay. MCF-10A, MCF-7 and MDA-MB 231 cells were harvested and seeded in a 96-well dish to a final concentration of $5 \times 10^{3}$ cells/well and incubated in DMEM containing $1 \%$ FBS for $24 \mathrm{~h}$. Cells were treated with the indicated concentrations of Rosmanol (Baoji Herbest Bio-tech Co., Ltd.), then incubated for $48 \mathrm{~h}$. Next, $20 \mu \mathrm{l}$ MTT (Sigma-Aldrich; Merck KGaA) solution (5 mg/ml) was added to each well and incubated for $4 \mathrm{~h}$ at $37^{\circ} \mathrm{C}$. Finally, the medium was discarded, and $150 \mu 1$ DMSO was added to each well. The plates were read at a wavelength of $570 \mathrm{~nm}$ using a Varioskan Flash Multimode Reader (Thermo Fisher Scientific, Inc.). Six duplicate wells were used for each treatment. The absorbance was measured at $570 \mathrm{~nm}$, results were expressed as a percentage, relative to solvent-control incubations, and the $\mathrm{IC}_{50}$ values were determined using non-linear regression analysis (percentage survival versus concentration).

Annexin V/PI assay for apoptosis. Apoptotic MCF-7 and MDA-MB 231 cells were investigated using the Annexin V/propidium iodide (PI) apoptosis detection kit (Beyotime Institute of Biotechnology) followed by flow cytometry, according to the manufacturer's protocol. MCF-7 and MDA-MB 231 cells $\left(5 \times 10^{3}\right.$ cells/well) were cultured in 6 -well plates and treated with different concentrations (15, 30 and $60 \mu \mathrm{M}$ ) of Rosmanol for $48 \mathrm{~h}$ at $37^{\circ} \mathrm{C}$. Cells were harvested by trypsinization with no EDTA and washed twice with PBS and then stained with $5 \mu$ l Annexin V-FITC (Beyotime Institute of Biotechnology) and $10 \mu \mathrm{l}$ PI in $500 \mu 1$ binding buffer for $15 \mathrm{~min}$ at room temperature (RT) in the dark. Apoptotic cells were determined by using Cytomics FC 500 flow cytometer (Beckman Coulter Inc.) and the data were analysed using Cellquest analysis software v.3.0 (BD Biosciences).

Determination of MCF-7 and MDA-MB 231 cell apoptosis by immunofluorescence. MCF-7 and MDA-MB 231 apoptotic cell death was observed by DAPI staining. Briefly, cells were treated with 15,30 and $60 \mu \mathrm{M}$ Rosmanol for $48 \mathrm{~h}$ at $37^{\circ} \mathrm{C}$, then fixed with $4 \%$ paraformaldehyde for $20 \mathrm{~min}$ at $4^{\circ} \mathrm{C}$. Subsequently, cells were washed with precooled PBS $\left(4^{\circ} \mathrm{C}\right)$, twice with TBST $(0.05 \%$ Tween 20$)$, and cells were stained with DAPI $(1 \mu \mathrm{g} / \mathrm{ml})$ at room temperature in the dark for $3 \mathrm{~min}$, and washed with PBS. Apoptotic nuclei cells were observed under a fluorescent microscope (model IX71; Olympus Corporation).

Determination of MCF-7 and MDA-MB 231 cell cycle distribution. The cell cycle distributions in different phases after exposure to Rosmanol were analyzed by flow cytometry. In brief, MCF-7 and MDA-MB 231 cells $\left(5 \times 10^{5}\right.$ cells/well) were seeded into 6-well plates and exposed to 15,30 and $60 \mu \mathrm{M}$ Rosmanol for $48 \mathrm{~h}$ at $37^{\circ} \mathrm{C}$. Further, the cells were harvested, washed twice with PBS, and fixed with $70 \%$ ethanol for $2 \mathrm{~h}$ at $4^{\circ} \mathrm{C}$. After that, cells were centrifuged at 3,000 $\mathrm{x}$ g for $5 \mathrm{~min}$ at $4^{\circ} \mathrm{C}$ and washed with PBS, resuspended in $500 \mu \mathrm{l}$ of buffer containing $0.5 \mathrm{mg} / \mathrm{ml}$ RNase and $25 \mathrm{mg} / \mathrm{ml}$ propidium iodide (PI, Beyotime Institute of Biotechnology), and incubated in the dark at $37^{\circ} \mathrm{C}$ for $15 \mathrm{~min}$. The distribution of the cell cycle was determined by using Cytomics FC 500 flow cytometer (Beckman Coulter Inc.), and the data were analyzed using Cellquest analysis software v.3.0 (BD Biosciences).

Determination of reactive oxygen species (ROS) expression in MCF-7 and MDA-MB 231 cells. The generation of ROS was determined with 2,7-dichlorofluorescein diacetate (DCFH-DA) according to the manufacturer's protocol. Briefly, MCF-7 and MDA-MB 231 cells were cultured $\left(5 \times 10^{3}\right.$ cells/well) and then incubated with or without N-acetyl-cysteine (NAC) for $1 \mathrm{~h}$ at $37^{\circ} \mathrm{C}$. After the culture was treated with 15,30 and $60 \mu \mathrm{M}$ of Rosmanol for $48 \mathrm{~h}$ at $37^{\circ} \mathrm{C}$. The cells were collected, centrifuged at $600 \mathrm{x} \mathrm{g}$ for $4 \mathrm{~min}$ at room temperature, washed with PBS, resuspended in PBS containing $10 \mu \mathrm{M}$ DCFH-DA (Beyotime Institute of Biotechnology) and incubated in the 

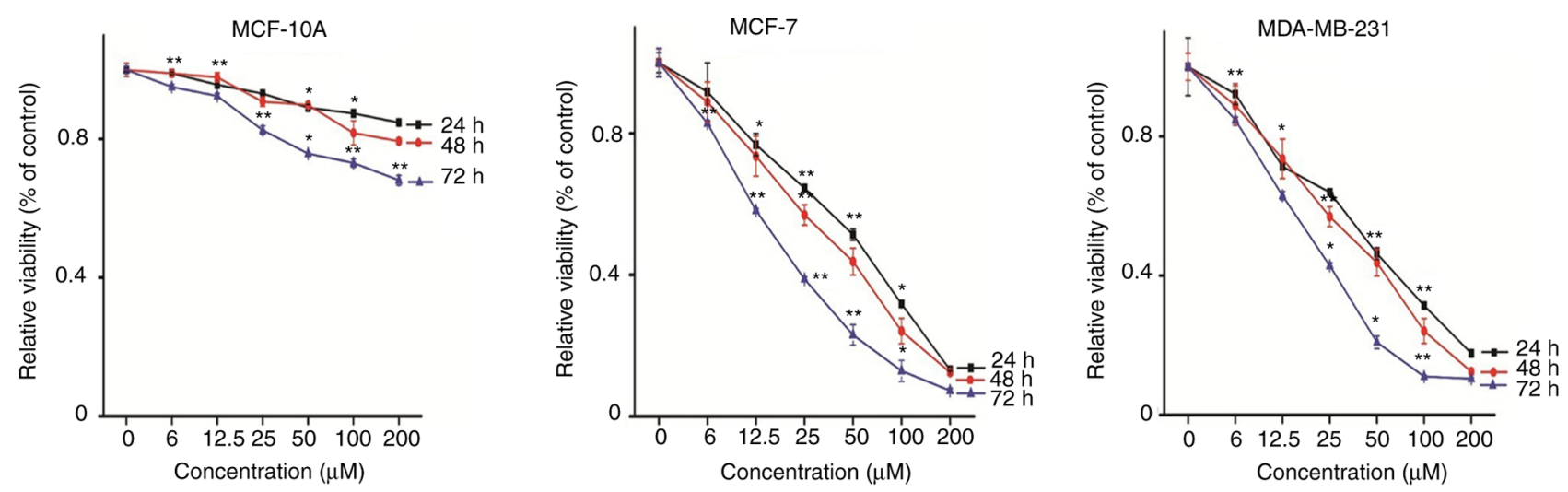

Figure 1. Cytotoxicity of Rosmanol in MCF-10A, MCF-7 and MDA-MB 231 cells. MCF-10A breast normal cells line, and MCF-7 and MDA-MB 231 breast cancer cells were examined for the effect of Rosmanol on cell viability via MTT assay. The cells were treated with the concentrations of $0,6,12.5,25,50,100$ and $200 \mu \mathrm{M}$ Rosmanol, and cell proliferation was assessed after 24, 48 and $72 \mathrm{~h}$. Each bar represents the mean \pm standard deviation of three experiments. ${ }^{*} \mathrm{P}<0.05$ and ${ }^{* *} \mathrm{P}<0.01$ vs. untreated group.

dark at RT for 15 min. Subsequently, the cells were washed with PBS and measured immediately using flow cytometry (Cytomics FC 500, Beckman Coulter, Inc.) to monitor the formation of the fluorescent-oxidized derivative of DCFH-DA at an emission wavelength of $525 \mathrm{~nm}$ and an excitation wavelength of $488 \mathrm{~nm}$.

Determination of mitochondrial membrane expression (MMP) in MCF-7 and MDA-MB 231 cells. The changes induced by Rosmanol in the mitochondrial membrane were determined using Rhodamine 123 staining (Beyotime Institute of Biotechnology) according to the manufacturer's protocol. Briefly, MCF-7 and MDA-MB 231 cells $\left(5 \times 10^{3}\right.$ cells/well) were seeded in 6-well plates and then treated with or without NAC and incubated at $37^{\circ} \mathrm{C}$ for $1 \mathrm{~h}$. The cells were treated with or without $(15,30$ and $60 \mu \mathrm{M})$ Rosmanol for $48 \mathrm{~h}$ at $37^{\circ} \mathrm{C}$ and stained with Rhodamine 123 for $15 \mathrm{~min}$ at $37^{\circ} \mathrm{C}$. Mitochondrial membrane potential was detected by Cytomics FC 500 flow cytometer (Beckman Coulter Inc.) and the data were analyzed using Cellquest analysis software v.3.0 (BD Biosciences).

Western blot analysis of MCF-7 and MDA-MB 231 cells. Protein expression regulation by Rosmanol was analyzed via western blotting and the data were analysed using Image J software v.1.48 (National Institutes of Health) following a protocol described previously (21) with a small modification. In brief, MCF-7 and MDA-MB 231 cells were seeded and incubated at $37^{\circ} \mathrm{C}$ for $24 \mathrm{~h}$ and were separated into 2 groups. Cells in one group were treated with 15,30 and $60 \mu \mathrm{M}$ Rosmanol for $48 \mathrm{~h}$ at $37^{\circ} \mathrm{C}$ and MCF-7 and MDA-MB 231 cells in the other group were pre-incubation with the caspase inhibitor Z-VAD-FMK $(50 \mathrm{mM}$; Sigma-Aldrich; Merck KGaA) at $37^{\circ} \mathrm{C}$ for $1 \mathrm{~h}$ and then treated with Rosmanol $(15,30$ and $60 \mu \mathrm{M})$ at $37^{\circ} \mathrm{C}$ for $48 \mathrm{~h}$. The cells were then harvested and lysed with RIPA buffer. Afterward, the insoluble protein lysate was removed by centrifugation at $12,000 \mathrm{x} \mathrm{g}$ for $15 \mathrm{~min}$ at $4^{\circ} \mathrm{C}$. Protein concentrations were determined using a NanoDrop 1000 (Thermo Fisher Scientific, Inc.). Proteins (40 $\mu \mathrm{g} /$ lane) were loaded on SDS-PAGE electrophoresis gel (10 or $12 \%$ according to the protein size), and the gel was transferred onto polyvinylidene fluoride membrane
(PVDF). After the necessary transfer time, the membrane was blocked in 5\% (w/v) non-fat milk and incubated for $1 \mathrm{~h}$ at room temperature. The membranes were incubated with appropriate primary antibodies, Caspase-3 (cat. no. 9662s), Caspase-8 (cat. no. 4927s), Caspase-9 (cat. no. 9502s), p-PI3k (cat. no. 4228), p-Akt (cat. no. 9271), Akt (cat. no. 9272), JAK2 (cat. no. 3230), p-JAK2 (cat. no. 3771), p-ERK (cat. no. 9101), p-p38 (cat. no. 9211), STAT3 (cat. no. 9139), p-STAT3 (cat.no. 9145), Bcl-2 (cat. no. 15071), Bax (cat.no. 2774), NF-KB (cat. no. 8242), Cox-2 (cat. no. 12282) (all 1:1,000; all Cell Signaling Technology, Inc.) and Cyclin A (cat. no. sc-271682), Cyclin B1 (cat. no. sc-245), Cyclin D1 (cat. no. sc-8396), Cyclin E1 (cat. no. sc-377100), ER- $\alpha$ (cat. no. sc8002) and ER- $\beta$ (cat. no. sc-373853) (all 1:2,000; all Santa Cruz Biotechnology) at $4^{\circ} \mathrm{C}$ overnight and washed three times with a Tris-buffered saline-Tween solution (TBST) containing $0.05 \%$ Tween 20 . Finally, the blots were incubated with horseradish peroxidase-conjugated goat anti-mouse IgG (1:1,000; cat. no. sc-2005; Santa Cruz Biotechnology, Inc.) and horseradish peroxidase-conjugated goat anti-rabbit IgG (1:1,000; cat. no. sc-2004; Santa Cruz Biotechnology, Inc.) for $1 \mathrm{~h}$ at RT, washed with TBST for $30 \mathrm{~min}$, and signals were detected using an ECL plus chemiluminescence kit on X-ray film (EMD Millipore) in a dark room or use Tanon 5500 high definition low illumination CCD system (Tanon Science \& Technology Co., Ltd.) to detect blot signals and TanonImage software v.1.00 (Tanon Science \& Technology Co., Ltd.) to capture and merge images. Protein bands were quantified by Image J software v.1.48 (National Institutes of Health).

Transient transfection and luciferase reporter as say of MCF-10A, MCF-7 and MDA-MB 231 cells. Luciferase assays were performed as previously described (22). Briefly, transient transfections were performed using Lipofectamine 2000 (Invitrogen; Thermo Fisher Scientific, Inc.) according to the manufacturer's protocol. Cells were seeded into 48 -well plates $\left(0.5 \times 10^{3}\right.$ cells/well $)$ at $37^{\circ} \mathrm{C}$ for $16 \mathrm{~h}$ before being transfected with $100 \mathrm{ng}$ STAT3-Luc promoter in the presence of $25 \mathrm{ng}$ Renilla Luciferase control pREP7 vector and incubated at $37^{\circ} \mathrm{C}$ for $24 \mathrm{~h}$. The cells were then treated with Rosmanol at concentrations of $0,15,30$ and $60 \mu \mathrm{M}$ for 
A
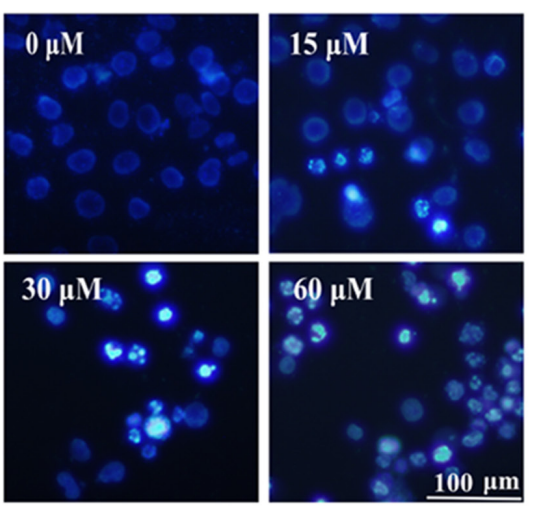

B
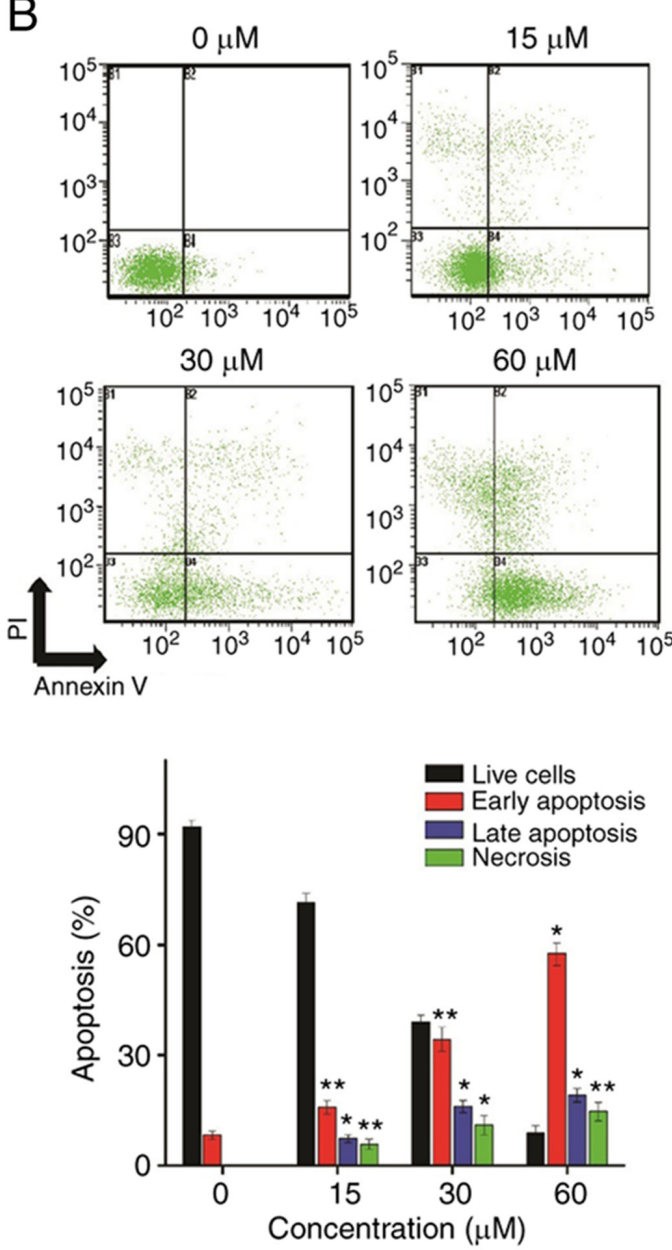
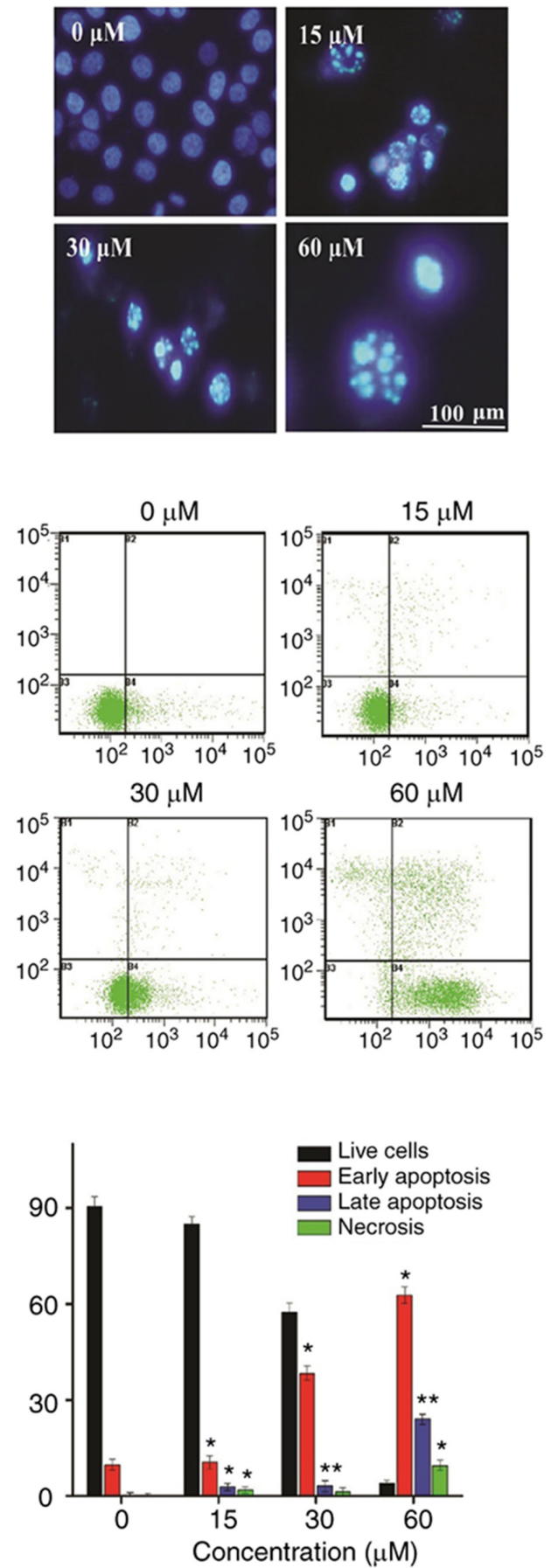

Figure 2. Contimued.

$24 \mathrm{~h}$ at $37^{\circ} \mathrm{C}$. Firefly luciferase activities were calculated using the Dual-Luciferase reporter assay system (Promega Corporation) and the ratio of firefly luciferase activity to Renilla luciferase activity was defined as relative luciferase activity.

Statistical analysis. All statistical analyses were performed using Origin Lab software version 8.0 (OriginLab), and statistically significant differences between groups were determined by one-way ANOVA with Bonferroni's post hoc test. $\mathrm{P}<0.05$ was considered to indicate a statistically significant difference.

\section{Results}

Cytotoxicity of Rosmanol on breast cancer and normal cell lines. First, the effect of Rosmanol on cell viability was investigated using the MTT assay. The cells were incubated with $0,6,12.5,25,50,100$ and $200 \mu \mathrm{M}$ Rosmanol. As shown in Fig. 1, Rosmanol was able to inhibit the proliferation of MCF-7 and MDA-MB 231 cells, suggesting that Rosmanol induced cytotoxicity against human breast cancer cells. It was revealed that Rosmanol induced cytotoxicity in MCF-7 and MDA-MB 231 cells not only in dose-dependent manner, but also in a time-dependent manner, with their 

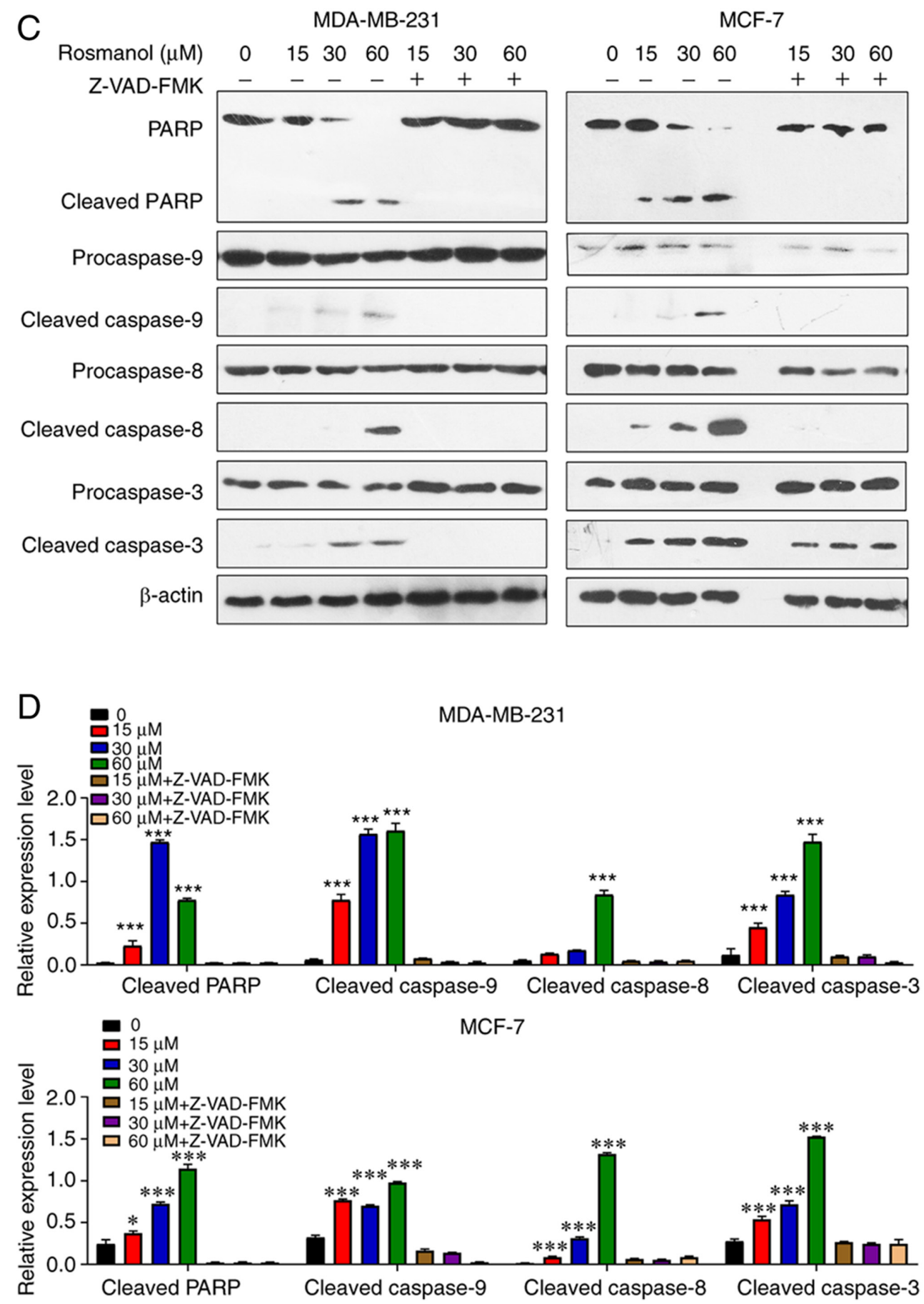

Figure 2. Rosmanol induces apoptosis in MCF-7 and MDA-MB 231 cells. (A) Morphological observation was firstly performed under a microscope. Exposure of MCF-7 and MDA-MB 231 cells to Rosmanol $(15,30$ and $60 \mu \mathrm{M})$ for $48 \mathrm{~h}$ induces cell membrane changes along with a shift in their nuclear morphology, as well as DNA damage compared with untreated cells, as shown by DAPI staining. (B) A measurement of apoptosis was determined by annexin V-FITC and PI double-staining flow cytometry, which can quantitatively assess early apoptosis (B4), late apoptosis (B2) and necrosis (B1). ${ }^{*} \mathrm{P}<0.05$, ${ }^{* * *} \mathrm{P}<0.01 \mathrm{vs}$. control. (C) MCF-7 and MDA-MB 231 cells were treated with Rosmanol (15, 30 and $60 \mu \mathrm{M})$ for $48 \mathrm{~h}$ in the presence or absence of caspase inhibitor Z-VAD-FMK, then the caspase levels were determined by western blotting. (D) These cleaved-caspase and cleaved-PARP protein bands of MDA-MB-231 cells (top graph) and MCF-7 cells (bottom graph) were quantified and statistically analyzed ( $\beta$-actin as an internal control). The data are presented as mean values \pm SD of three independent experiments. ${ }^{*} \mathrm{P}<0.05$ and ${ }^{* * *} \mathrm{P}<0.001$ vs. untreated group.

half maximal inhibitory concentration $\mathrm{IC}_{50}(51,26$ and 19$)$ and (42, 28 and 16) $\mu \mathrm{M}$, respectively, for 24,48 and $72 \mathrm{~h}$. However, Rosmanol did not exhibit a significant effect on MCF-10A normal breast cells. Thus, based on its effects on both MCF-7 and MDA-MB 231 cells, incubation at concentrations of 15,30 and $60 \mu \mathrm{M}$ for $48 \mathrm{~h}$ was chosen for subsequent studies.
Rosmanol induces apoptosis in MCF-7 and MDA-MB 231 cells. To determine whether the cytotoxicity exerted by Rosmanol was due to apoptosis induction, morphological observations were first performed under a microscope. The exposure of MCF-7 and MDA-MB 231 cells to Rosmanol $(15,30$ and $60 \mu \mathrm{M})$ for $48 \mathrm{~h}$ induced cell membrane changes along with a shift in their nuclear morphology, as well as DNA damage compared 


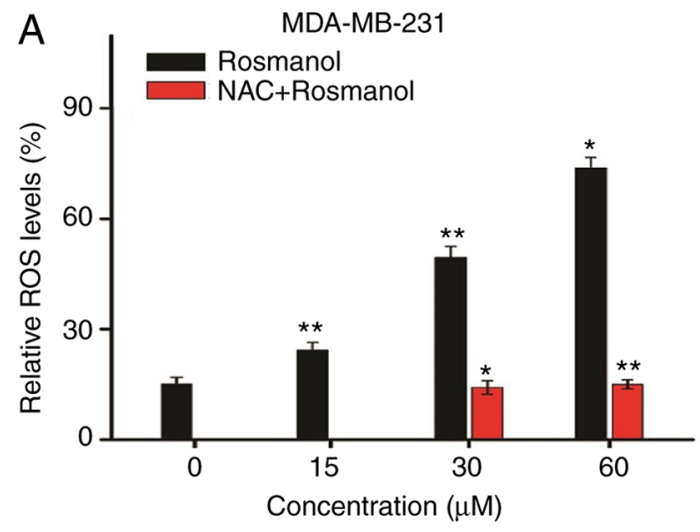

B

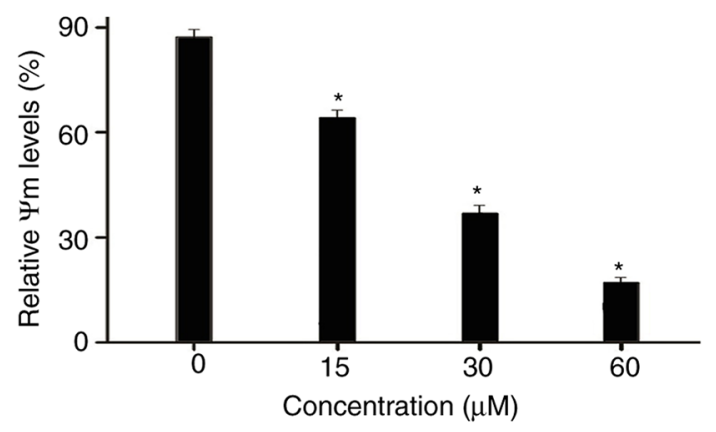

C

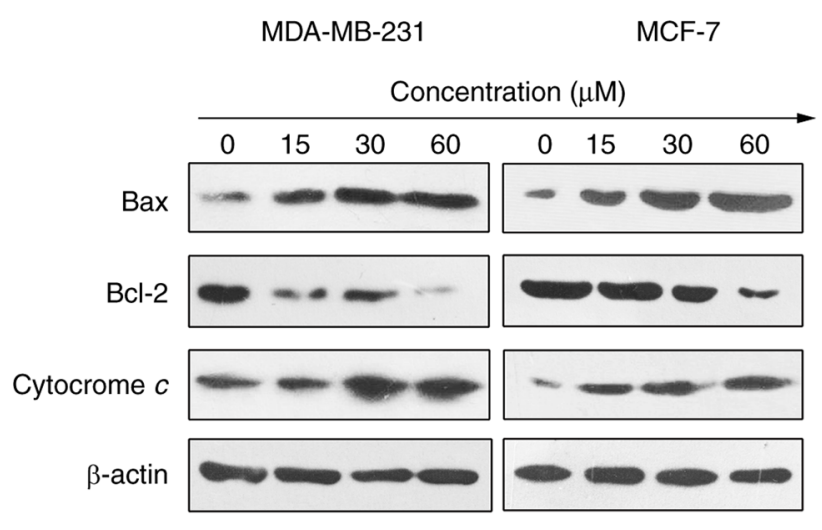

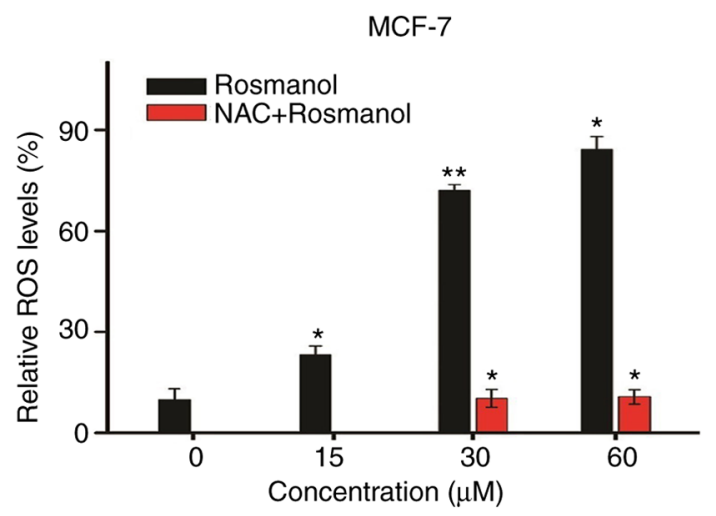
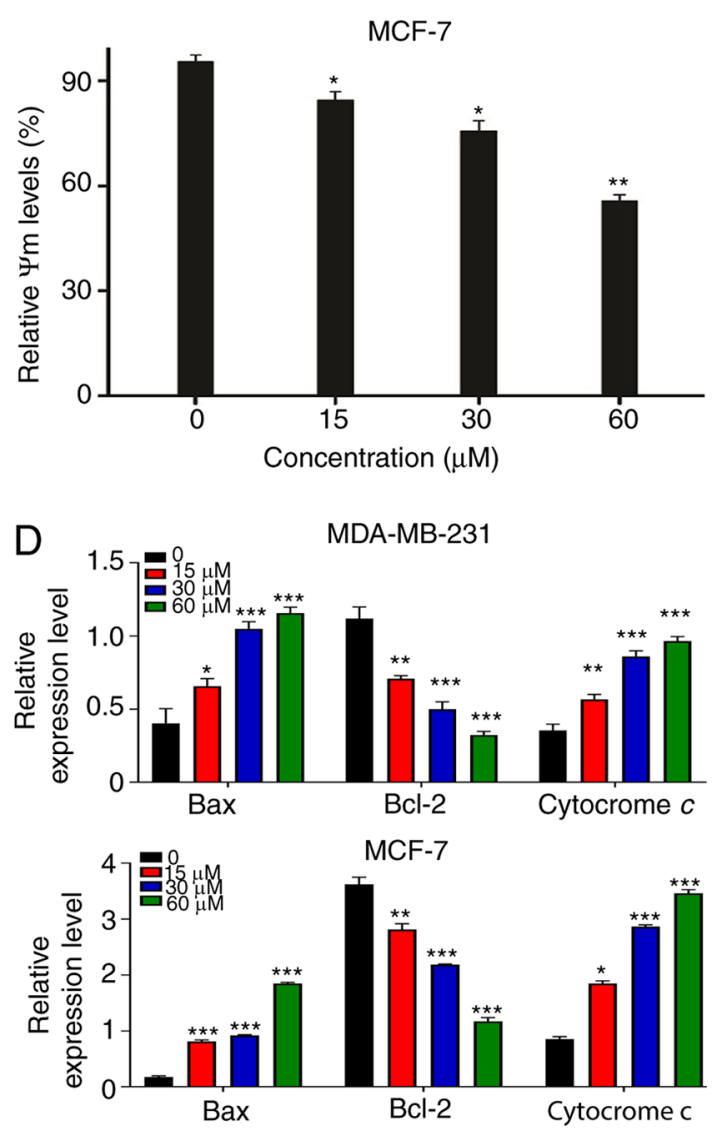

Figure 3. Rosmanol stimulates apoptosis through the mitochondrial pathway and ROS production. (A) To evaluate whether the cytotoxicity mediated by Rosmanol is associated with generation of ROS production, MCF-7 and MDA-MB 231 cells were treated with Rosmanol. They were then loaded with the fluorescent probe DCF-DA for the detection and assessment of $\mathrm{H}_{2} \mathrm{O}_{2}$ by flow cytometry in the presence and absence of $\mathrm{NAC}$ for $48 \mathrm{~h}$. $\mathrm{P}<0.05$, ${ }^{* *} \mathrm{P}<0.01$ vs. control. (B) The effect of Rosmanol on mitochondrial depolarization was investigated in MCF-7 and MDA-MB 231 cells through Rhodamine 123 staining flow cytometry. Each bar represents the mean \pm standard deviation of three experiments. ${ }^{*} \mathrm{P}<0.05$, ${ }^{* *} \mathrm{P}<0.01$ vs. control. (C) MCF-7 and MDA-MB 231 cells were treated with Rosmanol (15, 30 and $60 \mu \mathrm{M})$ for $48 \mathrm{~h}$, then the level of Bax, Bcl-2 and cytochrome $c$ were detected by western blotting. (D) These protein bands were quantified and statistically analyzed ( $\beta$-actin as an internal control). The data are presented as mean values \pm SD of three independent experiments. ${ }^{*} \mathrm{P}<0.05,{ }^{* *} \mathrm{P}<0.01$ and ${ }^{* * * *} \mathrm{P}<0.001$ vs. untreated group. NAC, $\mathrm{N}$-acetyl-cysteine; ROS, reactive oxygen species.

with untreated cells, as shown by DAPI staining. Within a certain range, the degree of apoptosis was more obvious as the Rosmanol concentration increased (Fig. 2A).

To verify the apoptosis induction by Rosmanol, a further measurement of apoptosis was determined by annexin V-FITC and PI double-staining flow cytometry, which can quantitatively assess early apoptosis (B4), late apoptosis (B2), and necrosis (B1). As shown in Fig. 2B, the B4 values increased with an increase in the Rosmanol concentration in both $\mathrm{MCF}-7$ and MDA-MB 231 cells.
To further understand the molecular mechanism by which Rosmanol mediated apoptosis in MCF-7 and MDA-MB 231 cells, western blotting was conducted to detect caspases, the critical regulators of apoptosis $(23,24)$. As illustrated in Fig. 2C and D, Rosmanol stimulated the activation of caspase-8, as well as caspase-9 which led to activated caspase-3 and consequently cleaved PARP, the major indicator enzyme of apoptosis. Furthermore, pre-incubation of MCF-7 and MDA-MB 231 cells with the caspase inhibitor Z-VAD-FMK (50 mM; Sigma-Aldrich; Merck KGaA) at $37^{\circ} \mathrm{C}$ for $1 \mathrm{~h}$ and 

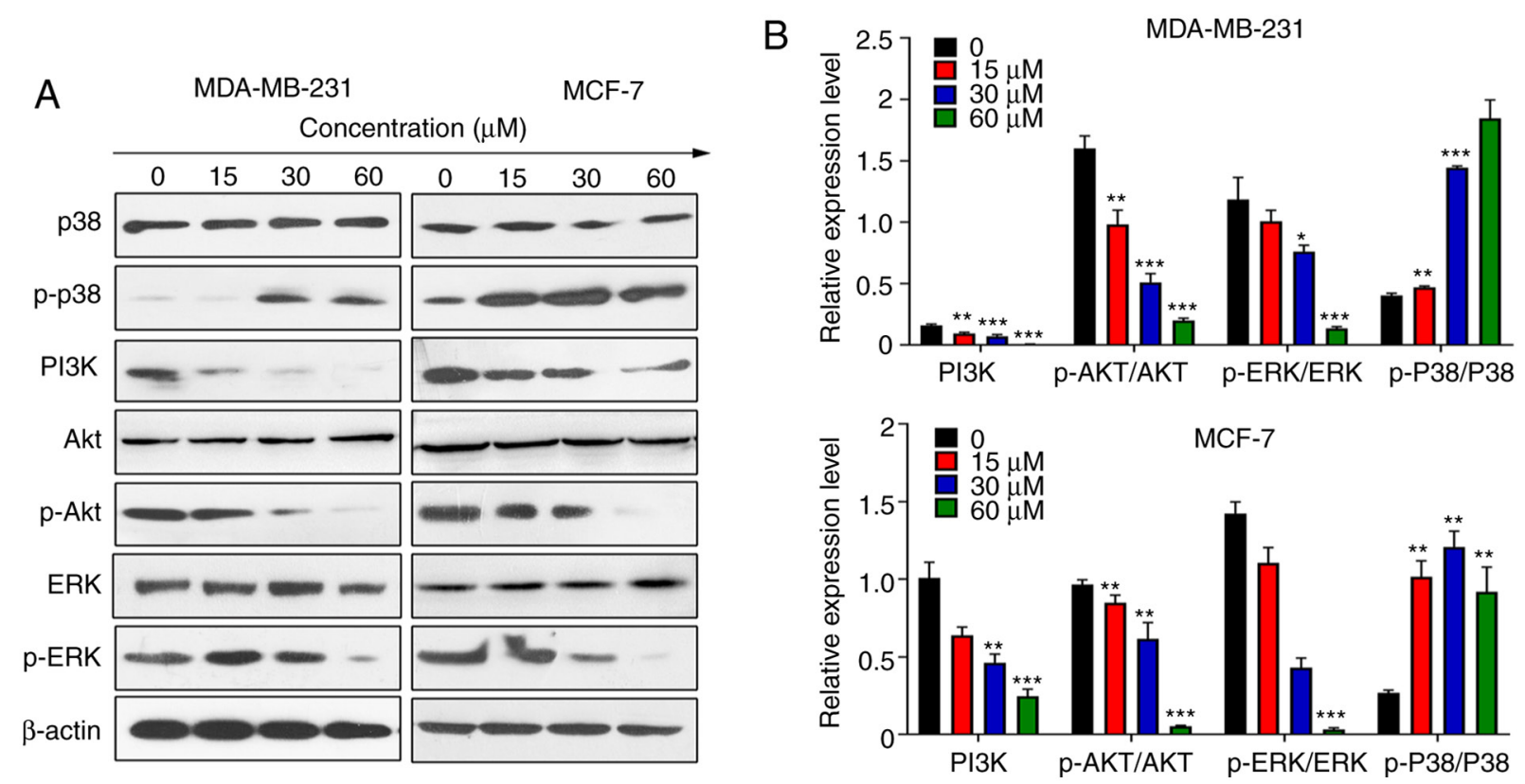

Figure 4. Rosmanol induces apoptosis via activation of p38/MAPK and inhibition of ERK1/2 and PI3K/Akt in MCF-7 and MDA-MB 231 cells. (A) Western blotting tested p38/MAPK, ERK1/2 and Akt proteins expression in MCF-7 and MDA-MB 231 cells treated with varying concentrations of Rosmanol. (B) These protein bands were quantified and statistically analyzed ( $\beta$-actin as an internal control). The data are presented as mean values \pm SD of three independent experiments. ${ }^{*} \mathrm{P}<0.05,{ }^{* * *} \mathrm{P}<0.01$ and ${ }^{* * * *} \mathrm{P}<0.001$ vs. untreated group. $\mathrm{p}-$, phosphorylated.

then treated with Rosmanol $(15,30$ and $60 \mu \mathrm{M})$ at $37^{\circ} \mathrm{C}$ for $48 \mathrm{~h}$ promoted the survival of the cells. These findings demonstrated that Rosmanol induced cancer cell apoptosis through extrinsic mitochondrial pathways.

Cytotoxicity mediated by Rosmanol is associated with generation of ROS. Immunostaining using DAPI revealed that Rosmanol induced DNA damage in MCF-7 and MDA-MB 213 cells. Previous studies reported that DNA damage induced oxidative stress in MCF-7 cells (25-27), which further resulted in the production of ROS (28). To evaluate whether the cytotoxicity mediated by Rosmanol was associated with the generation of ROS, MCF-7 and MDA-MB 231 cells were treated with Rosmanol, and then probed with the fluorescent DCF-DA for the detection and assessment of $\mathrm{H}_{2} \mathrm{O}_{2}$ by flow cytometry in the presence and absence of NAC for $48 \mathrm{~h}$. The results indicated that the generation of intracellular $\mathrm{H}_{2} \mathrm{O}_{2}$ increased considerably with the treatment of Rosmanol $(0,15,30$ and $60 \mu \mathrm{M})$. In the meantime, supplementation with NAC rendered ROS production almost unaffected by Rosmanol (30 and $60 \mu \mathrm{M}$ ), which indicated a role of Rosmanol in the generation of $\mathrm{H}_{2} \mathrm{O}_{2}$, as illustrated in Fig. 3A. These results demonstrated that Rosmanol increases ROS in MCF-7 and MDA-MB 231 cells, and that cytotoxicity is associated with the generation of ROS.

Rosmanol stimulates apoptosis via the mitochondrial pathway. To validate our hypotheses, the effect of Rosmanol on mitochondrial depolarization was investigated in MCF-7 and MDA-MB 231 cells through the employment of Rhodamine 123 staining flow cytometry. Targeting mitochondria is a novel approach for cancer therapy because of their ability for stimulating apoptosis. In in this regard, mitochondrial-mediated apoptosis can be highly regulated by counterbalancing the expression of pro-apoptotic, as well as anti-apoptotic, Bcl-2 proteins in which a loss in the mitochondrial transmembrane potential $(\Delta \psi \mathrm{m})$ ensues in the case of the disruption of these counterbalances (29). As shown in Fig. 3B, Rosmanol treatment of MCF-7 and MDA-MB 231 cells induced the loss of mitochondrial membrane potential. This decrease in mitochondrial membrane potential by Rosmanol was particularly caused by the capability of Rosmanol to release mitochondrial Cytochrome c, a major factor in the formation of apoptosomes (9), and in addition, to induce Bax and inhibit $\mathrm{Bcl}-2$, as shown in Fig. $3 \mathrm{C}$ and D. These findings indicate the role of Rosmanol in stimulating apoptosis via mitochondrial pathways.

Rosmanol induces activation of $p 38 / M A P K$ and prohibition of ERKand PI3K/Aktin MCF-7 and MDA-MB 231 cells.ER,NF- $\mathrm{BB}$ and ERK signals are significant in breast cancer (30). First, the possibility of ER signals being involved in Rosmanol-induced apoptosis was investigated, and the expression of $E R \alpha$ and $\operatorname{Er} \beta$ in MCF-7 ER-positive and MDA-MB231 ER-negative cells were analyzed via western blotting. It was revealed that Rosmanol did not induce ER expression in ER-negative MDA-MB231 cells, the data of which are not shown.

ERK1/2 is an important pathway regulating the signaling of multiple biological processes, such as cell proliferation and cell growth (31). The most classic signals in the ERK pathway are RAS and MAPK, and ERK is also activated by the AKT signal (32). p38/MAPK signaling is ubiquitous in normal and malignant cells and is activated in various cancer types (33). Certain studies have shown that the p38/MAPK pathway functions as a tumor suppressor by regulating tumor cell proliferation and transformation (34-38). The effect of Rosmanol on ERK signaling was investigated via western blotting, and it was revealed that the expression of p-ERK decreased significantly in MCF-7 and MDA-MB231 cells at 
A
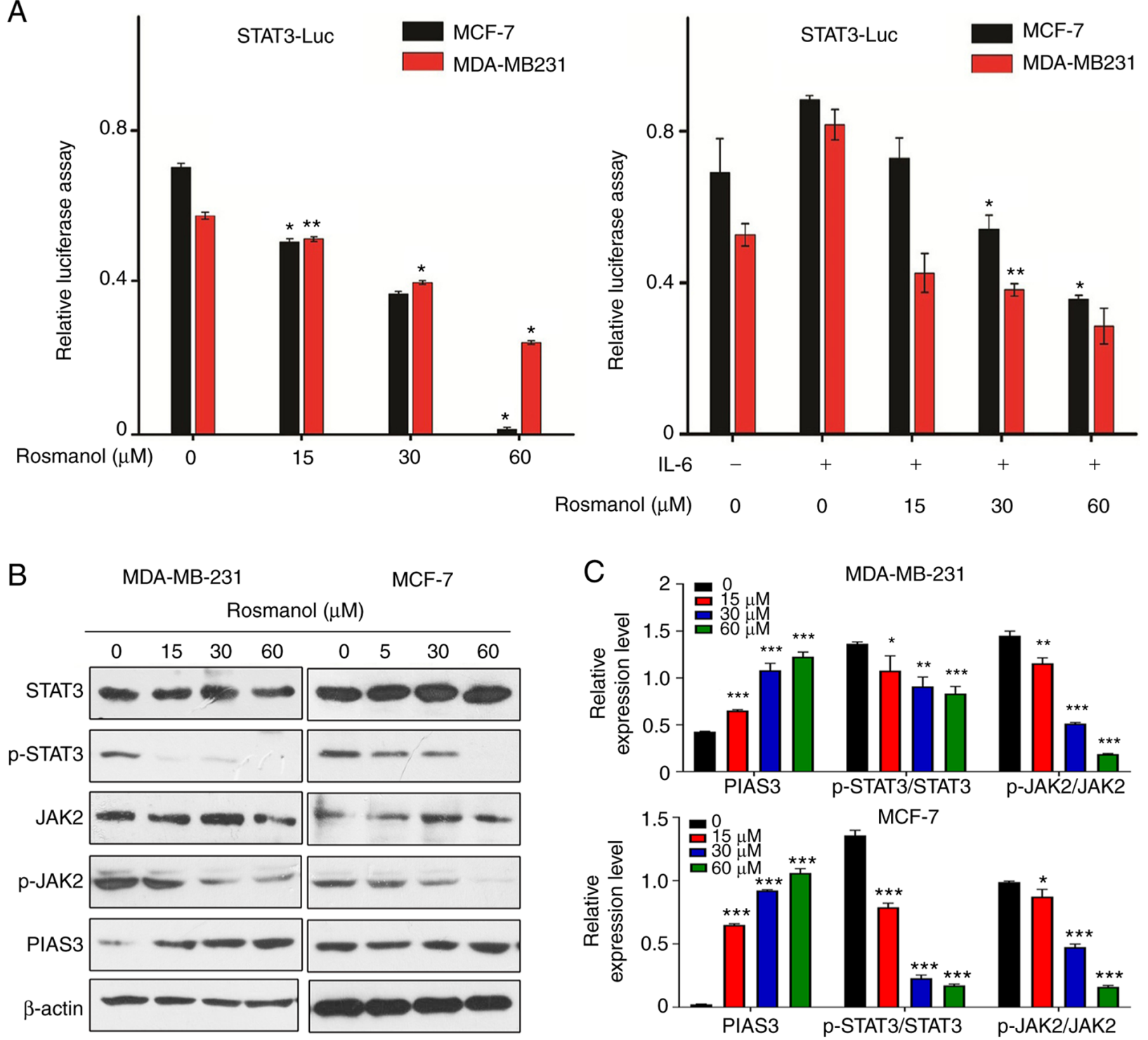

Figure 5. Rosmanol induces MCF-7 and MDA-MB 231 cell apoptosis through STA3/JAK2 prohibition and PIAS3 induction. (A) Transient transfection and luciferase tests of STAT3 were conducted in MCF-7 and MDA-MB 231 cells. Each bar represents the mean \pm standard deviation of three experiments. ${ }^{*} \mathrm{P}<0.05,{ }^{* *} \mathrm{P}<0.01$ vs. control. (B) MCF-7 and MDA-MB 231 cells were treated with different concentrations of Rosmanol, and then the level of STAT-3, p-STAT-3, JAK2, p-JAK2, and PIAS3 were detected by western blotting. (C) These protein bands were quantified and statistically analyzed ( $\beta$-actin as an internal control). The data are presented as mean $\pm \mathrm{SD}$ of three independent experiments. ${ }^{*} \mathrm{P}<0.05,{ }^{* *} \mathrm{P}<0.01$ and ${ }^{* * * *} \mathrm{P}<0.001$ vs. untreated group. Luc, luciferase; p, phosphorylated; PIAS3, protein inhibitor of activated STAT3.

varying concentrations (Fig. 4A and B). Concurrently, the p-p38 and PI3K/AKT signals were detected, in particular the dramatically increased expression of p-p38 and reduced expression of p-Akt and p-PI3K (Fig. 4A and B). Accordingly, it was demonstrated that the upregulation of p-p38 and the downregulation of PI3K/AKT regulate ERK signaling to participate in the apoptosis caused by Rosmanol.

Rosmanol inhibits the JAK2/ STAT3 pathway in MCF-7 and $M D A-M B$ 231cells. In tumors, STAT3 signaling is abnormally activated, which to drives the proliferation, survival, invasiveness, and metastasis of tumor cells, while strongly suppressing the apoptotic response (39). Subsequently, the effects of Rosmanol on the STAT3 pathway were investigated. Transient transfection and luciferase tests were conducted in MCF-7 and MDA-MB 231 cells to test the effects of Rosmanol on STAT3 transcription. Notably, Rosmanol significantly inhibited IL-6-induced STAT3 transcription in MCF-7 and MDA-MB 231 cells (Fig. 5A).

Protein inhibitor of activated STAT3 (PIAS3) was previously demonstrated to inhibit STAT3 transcriptional activity and promote growth inhibition in vitro (40). The regulation of PIAS3 expression by Rosmanol was then investigated in MCF-7 and MDA-MB 231 cells and found that Rosmanol induced increased PIAS3 expression in a dose-dependent manner (Fig. 5B and C). Rosmanol also decreased the level of phosphorylated STAT3 (Fig. 5B and C). The effect of Rosmanol on JAK2, the upstream signal of STAT3, was then investigated and it was revealed that it was significantly reduced (Fig. 5B and C). Therefore, it was demonstrated that Rosmanol inhibited the phosphorylation and transcription activity of STAT3 by augmenting PIAS3 or inhibiting the phosphorylation of JAK2. 
A

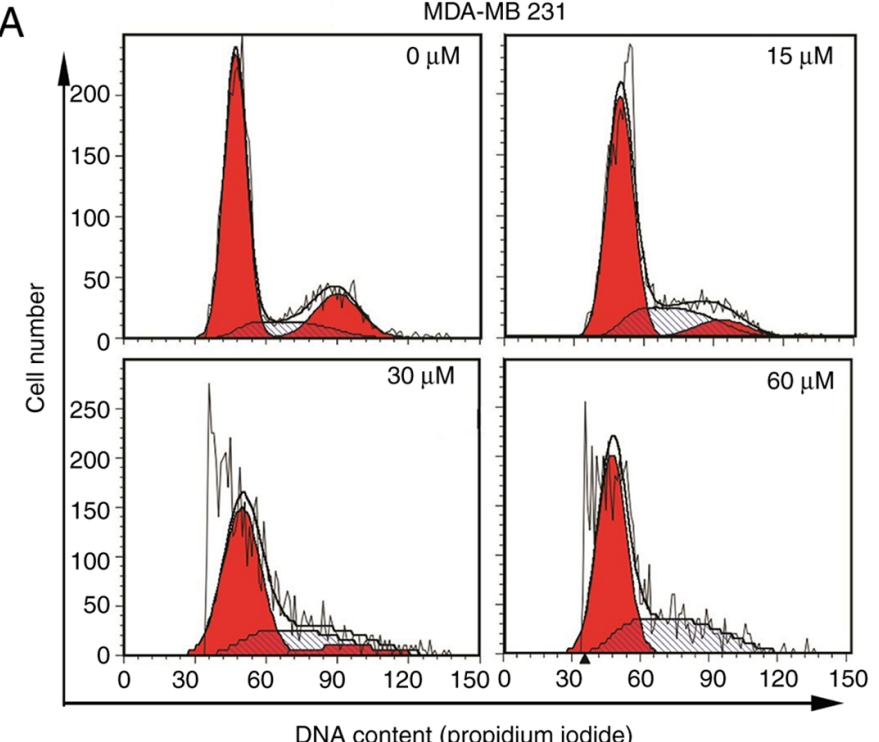

MCF-7

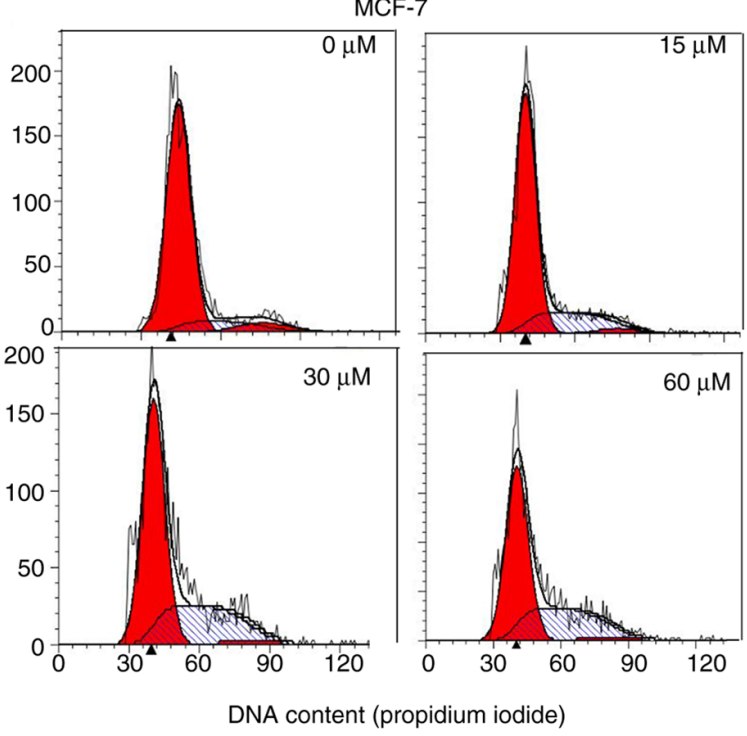

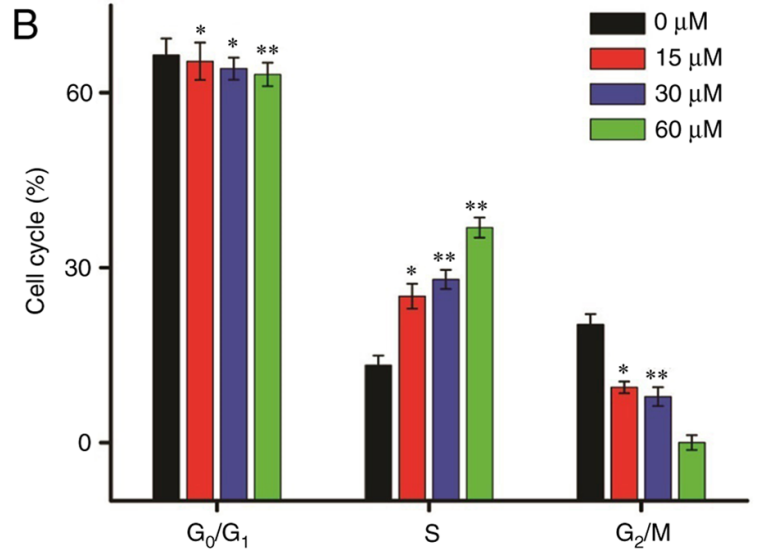

C

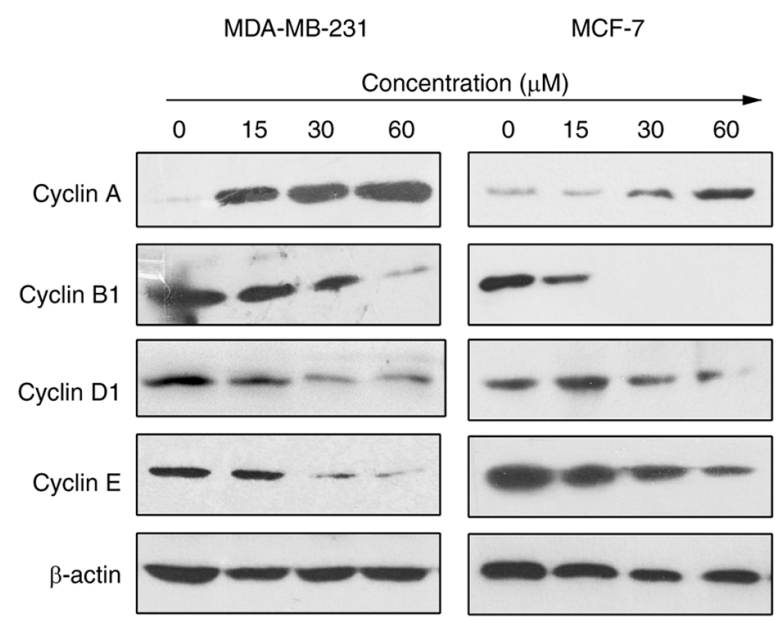

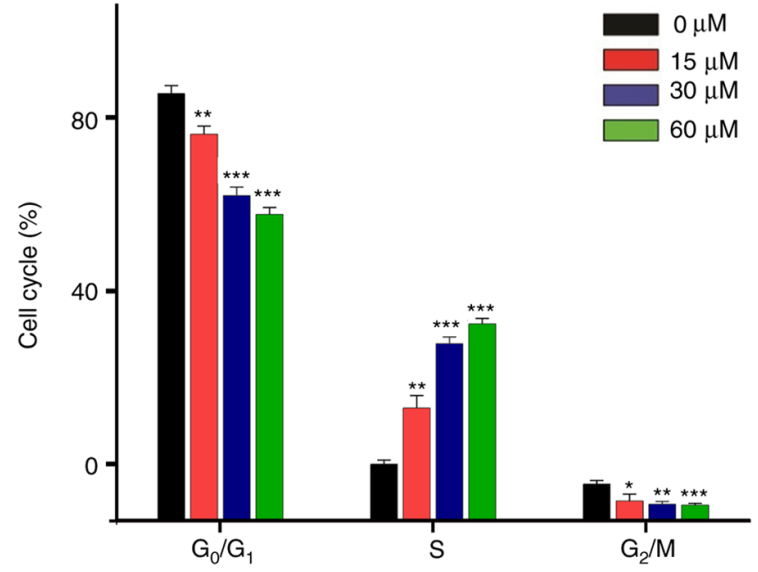

$\mathrm{D}$

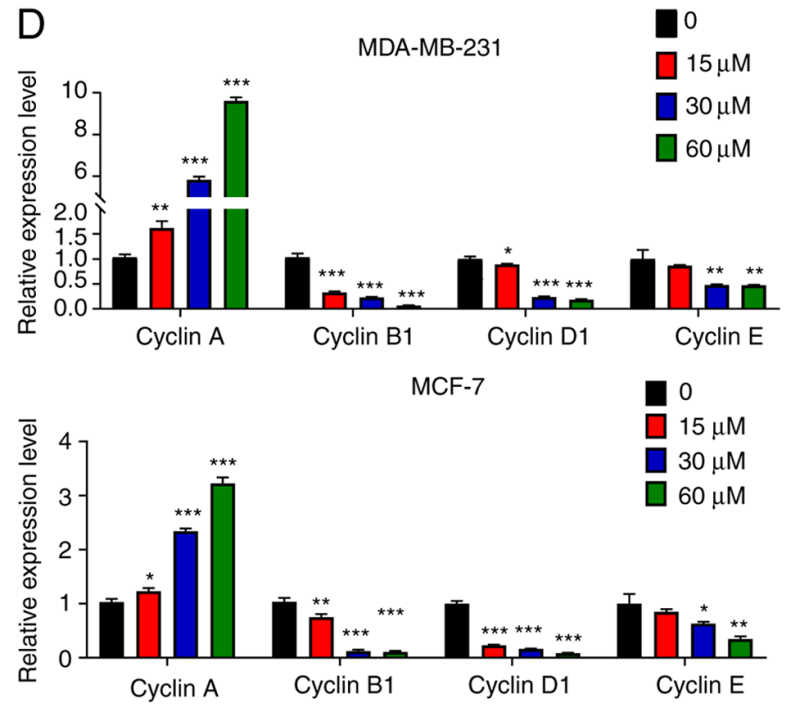

Figure 6. Rosmanol induces S phase cell cycle arrest in MCF-7 and MDA-MB 231 cells. (A) The cytotoxicity of Rosmanol in cell cycle arrest was evaluated by flow cytometry in MDA-MB 231 cells stimulated by Rosmanol. (B) Quantification of the cell cycle in (A). (C) Western blotting assays were performed to examine cycle proteins (Cyclin A, Cyclin B1, Cyclin D1 and Cyclin E) with regard S phase arrest in MCF-7 and MDA-MB-231 cells stimulated by Rosmanol. (D) These protein bands were quantified and statistically analyzed ( $\beta$-actin as an internal control). The data are presented as the mean \pm SD of three independent experiments. ${ }^{*} \mathrm{P}<0.05,{ }^{* *} \mathrm{P}<0.01$ and ${ }^{* * *} \mathrm{P}<0.001$ vs. untreated group.

Rosmanol induces $S$ phase cell cycle arrest in MCF-7 and $M D A-M B 231$ cells. It was demonstrated that Rosmanol inhibits several cell proliferation signals and at the same time promotes the apoptosis of mitochondrial signals. In this situation, whether the cytotoxicity of Rosmanol has an effect on the cell cycle was investigated. Flow cytometry was conducted to 


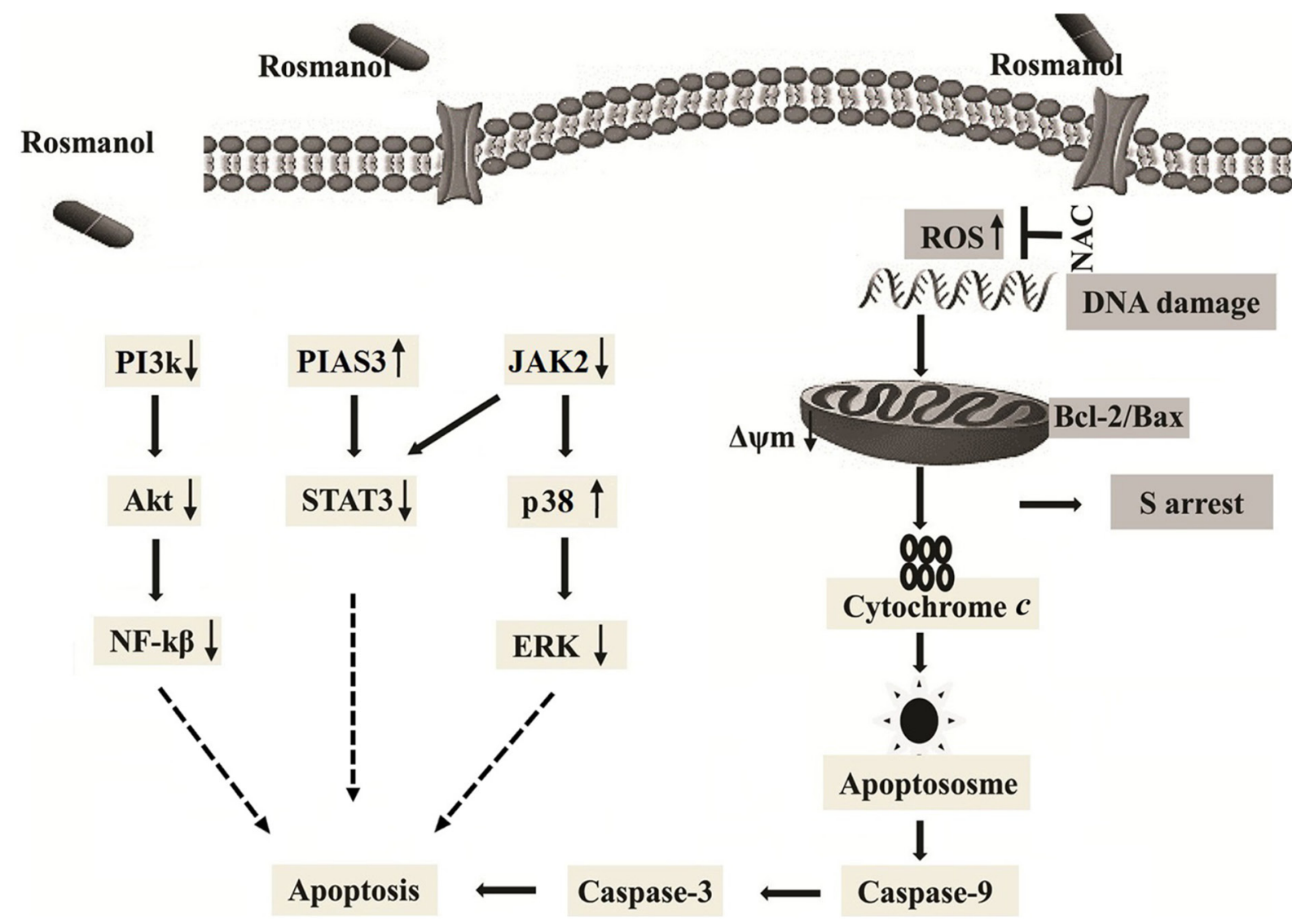

Figure 7. Mitochondrial anti-proliferative and pro-apoptotic role of Rosmanol in breast cancer cells. Rosmanol was found to trigger oxidative stress in MCF-7 and MDA-MB 231 cells, which in turn causes DNA damage resulting in cell cycle arrest at S phase. Furthermore, Rosmanol is effective at prohibiting JAK2/STAT3 and PI3K/AKT signaling. NAC, N-acetyl-cysteine; PIAS3, protein inhibitor of activated STAT3; ROS, reactive oxygen species.

check the cycle arrest in MCf-7 and MDA-MB 231 cells stimulated by Rosmanol (Fig. 6A and B), and the $\mathrm{S}$ phase showed a dose-dependent increase in Rosmanol, while the $G_{0} / G_{1}$ and $\mathrm{G}_{2} / \mathrm{M}$ percentages decreased, respectively, for the same treatment concentration. This proves that Rosmanol promotes $\mathrm{S}$ phase arrest.

Cyclins have been demonstrated as activators of specific serine/threonine protein kinases, and are vital cell cycle regulatory proteins that promote the cell cycle process $(41,42)$. Cyclin $\mathrm{A}$ is a marker in the $\mathrm{S}$ phase; it can activate two different cyclin-dependent kinases (CDKs) and is expressed primarily in the $\mathrm{S}$ phase (43). To further elucidate the molecular mechanism underlying S phase arrest in MCf-7 and MDA-MB 231 cells, western blotting was performed to describe the cyclin proteins regulating the cell cycle. As shown in Fig. 6C and D, Rosmanol increased Cyclin A expression, yet suppressed the expression of Cyclin E, Cyclin D1 and Cyclin B1 (Fig. 6C and D). These results demonstrate that Rosmanol induces $S$ phase arrest in MCf-7 and MDA-MB 231 cells.

\section{Discussion}

Rosmanol, an abundant natural product in the Salvia species, was demonstrated in the present study to promote breast cancer apoptosis in the mitochondrial pathway, simultaneously accelerating apoptosis and inhibiting cell proliferation via ERK and STAT3 signaling. It was also demonstrated that Rosmanol triggers oxidative stress in MCF-7 and MDA-MB231 cells and exerts anti-proliferation and mitochondrial apoptosis effects, depending on ROS-induced DNA damage. Moreover, Rosmanol accelerated the process of apoptosis through S-phase cell arrest. Moreover, it was found that Rosmanol induced apoptosis progression associated with the inhibition of STAT3 and ERK signaling, thereby preventing the proliferation of breast cancer MDA-MB 231 cells.

Rosmanol was demonstrated to inhibit the proliferation of MCF-7 and MDA-MB 231 cells and increased the apoptosis rate of MCF-7 and MDA-MB 231 cells. Rosmanol induced MCF-7 and MDA-MB 231 cell cytotoxicity with an $\mathrm{IC}_{50}$ (51, 26 and $19 \mu \mathrm{M})$ and $(42,28$ and $16 \mu \mathrm{M})$, respectively, for 24, 48 and 72 h. However, Rosmanol had no significant effect on MCF-10A normal breast cells. Notably, Rosmanol promoted the apoptotic process, by activating cysteine protease or poly (ADP-ribose) polymerase proteolysis in mitochondria, which further confirms that this process may be attenuated by the cysteine protease inhibitor Z-VAD-FMK. Rosmanol also stimulated apoptosis in human breast cancer MCF-7 and MDA-MB 231 cells. Flow cytometry revealed that Rosmanol increased ROS production which was attenuated by the manifestation of NAC. Furthermore, the generation of ROS is associated with improved cell apoptosis (44). These results affirmed the cytotoxicity of Rosmanol via the induction of ROS, an important apoptosis inducer, against human breast cancer MCF-7 and MDA-MB 231 cells. 
Cell proliferation, autoregulated by the cell cycle, is regulated via a myriad of complex cyclin proteins (45), while cyclin $B$ is required for cells to enter mitosis and $G_{2} / M$ transition (46). In addition, the $\mathrm{S}$ phase relies on a pathway to regulate Cyclin A synthesis (47). Here, it was demonstrated that the cytotoxicity of Rosmanol significantly inhibited the proliferation of cancer cells and that the channel of cells in the $G_{0} / G_{1}$ to $S$ phase was synchronized by cyclins. It was demonstrated that Rosmanol can stimulate MDA-MB 231 cell cycle arrest at the $\mathrm{S}$ phase by upregulating the expression of cyclin A and consequently downregulating the protein expression of Cyclin B1, Cyclin D1 and Cyclin E.

In tumor cells, ERK is often activated by Akt, and both of these Akt feedback signaling molecules serve a vital role in the proliferation and evasion of apoptosis in cells (48). A series of clinical trials are underway investigating the combined application of inhibitors that target the PI3K and MEK/ERK pathways, since single reagents have limited efficacy (49). The present study also demonstrated that Rosmanol functions as a potential natural antineoplastic alternative to the combination of Akt and ERK inhibitors, significantly inhibiting the Akt and ERK pathways, and considerably enhancing the antiproliferative effects of MCF-7 and MDA-MB 231 cells. NF- $\mathrm{BB}$ and Akt/ERK are two major cell-survival pathways that are often constitutively activated and communicate within cancer cells (50). p-p38 exerts a tumor suppressor effect. Here it was demonstrated that Rosmanol increases the expression of p-p38.

STAT proteins are critically involved in tumorigenesis in various cancers (51). PIAS3, the main cellular inhibitor of STAT3, has been described as a modulator of DNA-binding transcription factors (52). Activated JAKs phosphorylate STAT proteins, leading to their dimerization and translocation into the nucleus. In the nucleus, STATs act as transcription factors with pleiotropic downstream effects (53). In cancer cells, STAT3 activation leads to increased expression of downstream target genes, leading to increased cell proliferation (54). The present results showed that Rosmanol significantly inhibited IL-6-induced STAT3 transcription in MCF-7 and MDA-MB 231 cells, that the Rosmanol-induced increase in PIAS3 expression was dose-dependent and that Rosmanol inhibits JAK2 and STAT3 phosphorylation. It was demonstrated that Rosmanol augments PIAS3 expression and inhibits the JAK2/STA3 pathway.

The overall findings of the present study are summarized in Fig. 7, demonstrating that Rosmanol triggers oxidative stress causes ROS-induced DNA damage, and serves an anti-proliferative role with a mitochondrial apoptotic effect in MCF-7 and MDA-MB 231 cells. Rosmanol causes cancer cell arrest at the $\mathrm{S}$ phase in the cell cycle. Furthermore, it was demonstrated that Rosmanol has effective antiproliferative and anticancer effects via the inhibition of JAK2/STAT3 and PI3K/AKT signals.

\section{Acknowledgements}

Not applicable.

\section{Funding}

This study was supported by the Ministry of Science and Technology (grant no. 2021YFE0108000 and 2016YFE0128500), the National Natural Science Foundation of China (grant no. 31870758), the Jilin Provincial Science \& Technology Department (grant no.20200201025JC).

\section{Availability of data and materials}

All data generated or analyzed during this study are included in this published article.

\section{Authors' contributions}

DJ performed the cell and protein studies, analyzed the data, and drafted the manuscript. JX and SL participated in the cell and protein studies. MIN, XZ and XTL participated in analyzing the data, WW and TM performed cell cycle studies in MCF7 cells and cell apoptosis experiments by immunofluorescence in MDA-MB-231 cells after the article was submitted. JL and XML conceived the idea, designed the experiment, and drafted the manuscript. DJ and MIN confirmed the authenticity of all the raw data. All authors read and approved the final manuscript.

\section{Ethics approval and consent to participate}

Not applicable.

\section{Patient consent for publication}

Not applicable.

\section{Competing interests}

The authors declare that they have no competing interests.

\section{References}

1. Draper L: Breast cancer: Trends, risks, treatments, and effects. AAOHN J 54: 445-453, 2006.

2. Bleicher RJ: Timing and delays in breast cancer evaluation and treatment. Ann Surg Oncol 25: 2829-2838, 2018.

3. Castaneda SA and Strasser J: Updates in the treatment of breast cancer with radiotherapy. Surg Oncol Clin N Am 26: 371-382, 2017.

4. Quintela-Fandino M, Soberon N, Lluch A, Manso L, Calvo I, Cortes J, Moreno-Antón F, Gil-Gil M, Martinez-Jánez N, Gonzalez-Martin A, et al: Critically short telomeres and toxicity of chemotherapy in early breast cancer. Oncotarget 8: 21472-21482, 2017.

5. Kuete V, Mbaveng AT, Nono EC, Simo CC, Zeino M, Nkengfack AE and Efferth T: Cytotoxicity of seven naturally occurring phenolic compounds towards multi-factorial drug-resistant cancer cells. Phytomedicine 23: 856-863, 2016.

6. Lucas L, Russell A and Keast R: Molecular mechanisms of inflammation. Anti-inflammatory benefits of virgin olive oil and the phenolic compound oleocanthal. Curr Pharm Des 17: 754-768, 2011.

7. Petiwala SM and Johnson JJ: Diterpenes from rosemary (Rosmarinus officinalis): Defining their potential for anti-cancer activity. Cancer Lett 367: 93-102, 2015.

8. Lai CS, Lee JH, Ho CT, Liu CB, Wang JM, Wang YJ and Pan MH: Rosmanol potently inhibits lipopolysaccharide-induced iNOS and COX-2 expression through downregulating MAPK, NF-kappaB, STAT3 and C/EBP signaling pathways. J Agric Food Chem 57: 10990-10998, 2009.

9. Cheng AC, Lee MF, Tsai ML, Lai CS, Lee JH, Ho CT and Pan MH: Rosmanol potently induces apoptosis through both the mitochondrial apoptotic pathway and death receptor pathway in human colon adenocarcinoma COLO 205 cells. Food Chem Toxicol 49: 485-493, 2011. 
10. Tabata K, Kim M, Makino M, Satoh M, Satoh Y and Suzuki T: Phenolic diterpenes derived from Hyptis incana induce apoptosis and $\mathrm{G}(2) / \mathrm{M}$ arrest of neuroblastoma cells. Anticancer Res 32: 4781-4789, 2012.

11. Cheng M, Michalski S and Kommagani R: Role for growth regulation by estrogen in breast cancer 1 (GREB1) in hormone-dependent cancers. Int J Mol Sci 19: 2543, 2018.

12. Mishra AK, Abrahamsson A and Dabrosin C: Fulvestrant inhibits growth of triple negative breast cancer and synergizes with tamoxifen in ER $\alpha$ positive breast cancer by up-regulation of ER $\beta$. Oncotarget 7: 56876-56888, 2016.

13. Sharma VR, Gupta GK, Sharma AK, Batra N, Sharma DK, Joshi A and Sharma AK: PI3K/Akt/mTOR intracellular pathway and breast cancer: Factors, mechanism and regulation. Curr Pharm Des 23: 1633-1638, 2017.

14. Yu M, Qi B, Xiaoxiang W, Xu J and Liu X: Baicalein increases cisplatin sensitivity of A549 lung adenocarcinoma cells via PI3K/Akt/NF- $\kappa$ B pathway. Biomed Pharmacother 90: 677-685, 2017.

15. Voskas D, Ling LS and Woodgett JR: Signals controlling un-differentiated states in embryonic stem and cancer cells: Role of the phosphatidylinositol 3'kinase pathway. J Cell Physiol 229: 1312-1322, 2014

16. Huth HW, Albarnaz JD, Torres AA, Bonjardim CA and Ropert C: MEK2 controls the activation of MKK3/MKK6-p38 axis involved in the MDA-MB-231 breast cancer cell survival: Correlation with cyclin D1 expression. Cell Signal 28: 1283-1291, 2016.

17. Heckler MM, Thakor H, Schafer CC and Riggins RB: ERK/MAPK regulates ERR $\gamma$ expression, transcriptional activity and receptor-mediated tamoxifen resistance in ER+ breast cancer. FEBS J 281: 2431-2442, 2014.

18. Harrison DA, Binari R, Nahreini TS, Gilman M and Perrimon N: Activation of a Drosophila Janus kinase (JAK) causes hematopoietic neoplasia and developmental defects. EMBO J 14 2857-2865, 1995

19. Zhang Z, Wang F, Du C, Guo H, Ma L, Liu X, Kornmann M, Tian $\mathrm{X}$ and Yang Y: BRM/SMARCA2 promotes the proliferation and chemoresistance of pancreatic cancer cells by targeting JAK2/STAT3 signaling. Cancer Lett 402: 213-224, 2017.

20. Ho JM, Nguyen MH, Dierov JK, Badger KM, Beattie BK, Tartaro P, Haq R, Zanke BW, Carroll MP and Barber DL: TEL-JAK2 constitutively activates the extracellular signal-regulated kinase (ERK), stress-activated protein/Jun kinase (SAPK/JNK), and p38 signaling pathways. Blood 100 $1438-1448,2002$.

21. Nasser MI, Masood M, Wei W, Li X, Zhou Y, Liu B, Li J and Li X: Cordycepin induces apoptosis in SGC7901 cells through mitochondrial extrinsic phosphorylation of PI3K/Akt by generating ROS. Int J Oncol 50: 911-919, 2017.

22. Jiang C, Masood M, Rasul A, Wei W, Wang Y, Ali M, Mustaqeem M, Li J and Li X: Altholactone inhibits NF- $\kappa B$ and STAT3 activation and induces reactive oxygen species-mediated apoptosis in prostate cancer DU145 Cells. Molecules 22: 240, 2017.

23. Fan TJ, Han LH, Cong RS and Liang J: Caspase family proteases and apoptosis. Acta Biochim Biophys Sin (Shanghai) 37: 719-727, 2005 .

24. Shi Y: Mechanisms of caspase activation and inhibition during apoptosis. Mol Cell 9: 459-470, 2002.

25. Marinello PC, da Silva TN, Panis C, Neves AF, Machado KL, Borges FH, Guarnier FA, Bernardes SS, de-Freitas-Junior JC, Morgado-Díaz JA, et al: Mechanism of metformin action in MCF-7 and MDA-MB-231 human breast cancer cells involves oxidative stress generation, DNA damage, and transforming growth factor $\beta 1$ induction. Tumour Biol 37 : 5337-5346, 2016

26. Vrhovac Madunić I, Madunić J, Antunović M, Paradžik M, Garaj-Vrhovac V, Breljak D, Marijanović I and Gajski G: Apigenin, a dietary flavonoid, induces apoptosis, DNA damage, and oxidative stress in human breast cancer MCF-7 and MDA MB-231 cells. Naunyn Schmiedebergs Arch Pharmacol 391: 537-550, 2018

27. Kello M, Takac P, Kubatka P, Kuruc T, Petrova K and Mojzis J: Oxidative stress-induced DNA damage and apoptosis in clove buds-treated MCF-7 cells. Biomolecules 10: 139, 2020.

28. Bakhtiari E, Hosseini A and Mousavi SH: The role of ROS and $\mathrm{NF}-\kappa \mathrm{B}$ pathway in olmesartan induced-toxicity in HeLa and mcf-7 cell lines. Biomed Pharmacother 93: 429-434, 2017.
29. Fumarola C, Caffarra C, La Monica S, Galetti M, Alfieri RR, Cavazzoni A, Galvani E, Generali D, Petronini PG and Bonelli MA: Effects of sorafenib on energy metabolism in breast cancer cells: Role of AMPK-mTORC1 signaling. Breast Cancer Res Treat 141: 67-78, 2013.

30. Haldosén LA, Zhao C and Dahlman-Wright K: Estrogen receptor beta in breast cancer. Mol Cell Endocrinol 382: 665-672, 2014.

31. Sun Y, Liu WZ, Liu T, Feng X, Yang N and Zhou HF: Signaling pathway of MAPK/ERK in cell proliferation, differentiation, migration, senescence and apoptosis. J Recept Signal Transduct Res 35: 600-604, 2015.

32. Cakir M and Grossman AB: Targeting MAPK (Ras/ERK) and PI3K/Akt pathways in pituitary tumorigenesis. Expert Opin Ther Targets 13: 1121-1134, 2009.

33. Lee S, Rauch J and Kolch W: Targeting MAPK signaling in cancer: Mechanisms of drug resistance and sensitivity. Int J Mol Sci 21: 1102, 2020

34. Loesch M and Chen G: The p38 MAPK stress pathway as a tumor suppressor or more? Front Biosci 13: 3581-3593, 2008.

35. Wang J, Liu Z, Feng X, Gao S, Xu S and Liu P: Tumor suppressor gene ING3 induces cardiomyocyte hypertrophy via inhibition of AMPK and activation of p38 MAPK signaling. Arch Biochem Biophys 562: 22-30, 2014.

36. Martínez-Limón A, Joaquin M, Caballero M, Posas F and de Nadal E: The p38 pathway: From biology to cancer therapy. Int J Mol Sci 21: 1913, 2020.

37. Yu Z, Du Y, Li H, Huang J, Jiang D, Fan J, Shen Y, Zhang L, $\mathrm{Yu} \mathrm{X}, \mathrm{Xu} \mathrm{N}$ and Ke Q: miR-642 serves as a tumor suppressor in hepatocellular carcinoma by regulating SEMA4C and p38 MAPK signaling pathway. Oncol Lett 20: 74, 2020.

38. Hong B, Li H, Zhang M, Xu J, Lu Y, Zheng Y, Qian J, Chang JT, Yang $J$ and Yi Q: p38 MAPK inhibits breast cancer metastasis through regulation of stromal expansion. Int J Cancer 136: 34-43, 2015.

39. Dabir S, Kluge A, Kresak A, Yang M, Fu P, Groner B, Wildey G and Dowlati A: Low PIAS3 expression in malignant mesothelioma is associated with increased STAT3 activation and poor patient survival. Clin Cancer Res 20: 5124-5132, 2014.

40. Aghazadeh S and Yazdanparast R: Mycophenolic acid potentiates HER2-overexpressing SKBR3 breast cancer cell line to induce apoptosis: Involvement of AKT/FOXO1 and JAK2/STAT3 pathways. Apoptosis 21: 1302-1314, 2016.

41. Liang W, Guan H, He X, Ke W, Xu L, Liu L, Xiao H and Li Y: Down-regulation of SOSTDC1 promotes thyroid cancer cell proliferation via regulating cyclin A2 and cyclin E2. Oncotarget 6: 31780-31791, 2015

42. Geng Y, Michowski W, Chick JM, Wang YE, Jecrois ME, Sweeney KE, Liu L, Han RC, Ke N, Zagozdzon A, et al: Kinase-independent function of E-type cyclins in liver cancer. Proc Natl Acad Sci USA 115: 1015-1020, 2018.

43. Yam CH, Fung TK and Poon RY: Cyclin A in cell cycle control and cancer. Cell Mol Life Sci 59: 1317-1326, 2002

44. Mehdad A, Brumana G, Souza AA, Barbosa J, Ventura MM and de Freitas SM: A Bowman-Birk inhibitor induces apoptosis in human breast adenocarcinoma through mitochondrial impairment and oxidative damage following proteasome $20 \mathrm{~S}$ inhibition. Cell Death Discov 2: 15067, 2016.

45. Lim S and Kaldis P: Cdks, cyclins and CKIs: Roles beyond cell cycle regulation. Development 140: 3079-3093, 2013.

46. Timofeev O, Cizmecioglu O, Settele F, Kempf T and Hoffmann I: Cdc25 phosphatases are required for timely assembly of CDK1-cyclin B at the G2/M transition. J Biol Chem 285: 16978-16990, 2010.

47. Moulager M, Corellou F, Vergé V, Escande ML and Bouget FY: Integration of light signals by the retinoblastoma pathway in the control of $\mathrm{S}$ phase entry in the picophytoplanktonic cell Ostreococcus. PLoS Genet 56: e1000957, 2010.

48. Wang M, Shu ZJ, Wang Y and Peng W: Stachydrine hydrochloride inhibits proliferation and induces apoptosis of breast cancer cells via inhibition of Akt and ERK pathways. Am J Transl Res 9: 1834-1844, 2017.

49. Asati V, Mahapatra DK and Bharti SK: PI3K/Akt/mTOR and Ras/Raf/MEK/ERK signaling pathways inhibitors as anticancer agents: Structural and pharmacological perspectives. Eur J Med Chem 109: 314-341, 2016.

50. Sun H, Zheng X, Wang Q, Yan J, Li D, Zhou Y, Lin Y, Zhang L and Wang X: Concurrent blockade of NF- $\kappa$ B and Akt pathways potentiates cisplatin's antitumor activity in vivo. Anticancer Drugs 23: 1039-1046, 2012. 
51. Pastuszak-Lewandoska D, Domańska-Senderowska D, Kordiak J, Antczak A, Czarnecka KH, Migdalska-Sęk M, Nawrot E, Kiszałkiewicz JM and Brzeziańska-Lasota E: Immunoexpression analysis of selected JAK/STAT pathway molecules in patients with non-small-cell lung cancer. Pol Arch Intern Med 127: 758-764, 2017.

52. Yagil Z, Nechushtan H, Kay G, Yang CM, Kemeny DM and Razin E: The enigma of the role of protein inhibitor of activated STAT3 (PIAS3) in the immune response. Trends Immunol 31: 199-204, 2010
53. Yang X, Tang Z, Zhang P and Zhang L: Research advances of JAK/STAT signaling pathway in lung cancer. Zhongguo Fei Ai Za Zhi 22: 45-51, 2019 (In Chinese).

54. Lu Y, Zhou J, Xu C, Lin H, Xiao J, Wang Z and Yang B: JAK/STAT and PI3K/AKT pathways form a mutual transactivation loop and afford resistance to oxidative stress-induced apoptosis in cardiomyocytes. Cell Physiol Biochem 21: 305-314, 2008.

(c) (i) () $९$ This work is licensed under a Creative Commons C. At 1 A NDibution-NonCommercial-NoDerivatives 4.0 International (CC BY-NC-ND 4.0) License. 